\title{
Using Media Literacy to Counter Stereotypical Images of Blacks and Latinos at a Predominantly White University
}

\section{Joseph Erba, Yvonnes Chen \& Ms Hannah Kang}

To cite this article: Joseph Erba, Yvonnes Chen \& Ms Hannah Kang (2018): Using Media Literacy to Counter Stereotypical Images of Blacks and Latinos at a Predominantly White University, Howard Journal of Communications, DOI: 10.1080/10646175.2018.1423652

To link to this article: https://doi.org/10.1080/10646175.2018.1423652

曲 Published online: 31 Jan 2018.

Submit your article to this journal $\pi$

Џ Article views: 51

View Crossmark data $\complement$ 


\title{
Using Media Literacy to Counter Stereotypical Images of Blacks and Latinos at a Predominantly White University
}

\author{
Joseph Erba, Yvonnes Chen, and Ms Hannah Kang \\ William Allen White School of Journalism and Mass Communications, University of Kansas, Lawrence, \\ United States
}

\begin{abstract}
Media literacy, the critical analysis and deconstruction of media messages, has the potential to promote favorable attitudes toward members of racial minority groups. This study reports on the development and implementation of two types of media literacy interventions (i.e., critical and stereotype) aimed at enhancing college students' attitudes toward Blacks and Latinos. Students from 5 sections of the same course took part in a quasi-experiment and were randomly assigned to 1 of the 2 interventions or to a control group. Students' attitudes were measured at 3 different times during the study: 6 weeks before the intervention, immediately following the intervention, and 6 weeks after the intervention. Both interventions enhanced students' attitudes toward Blacks and Latinos but the stereotype intervention was more effective than the critical one, both for short- and long-term effects, as the latter disappeared in the critical condition. Attitudes of students in the control group remained the same throughout the study. Implications address how to use media literacy to enhance conversation about race relations.
\end{abstract}

\section{KEYTERMS}

Media; media literacy; race; stereotype/prejudice/bias

At the dawn of the $21^{\text {st }}$ century, White college students were found to continue to hold negative attitudes toward Black students (Carter, 1990). Pope-Davis and Ottavi (1994) went as far as stating that "the 1990s have started much the same as the 1960s began on most university campuses. Unpleasant racial and ethnic incidents are in abundance, attitudes and values are being tested, and tolerance for cultural diversity is once more being encouraged" (p. 293). A cursory look at news stories in the past few years is enough to realize that Pope-Davis and Ottavi's words still ring true today. ${ }^{1}$ One of the most covered stories has dealt with a series of blatant acts of racial discrimination at the University of Missouri, mainly aimed at Black students. The lack of response from the university's leadership eventually led to the resignation of the university chancellor and of the president of the university system (Deutsch, 2015).

CONTACT Joseph Erba erba@ku.edu William Allen White School of Journalism and Mass Communications, University of Kansas, 1435 Jayhawk Boulevard, Lawrence, KS 66045. 
As the number of non-White students at U.S. universities continues to increase, having doubled in the last 25 years, from $20.1 \%$ in 1990 to $41.7 \%$ in 2014 (U.S. Department of Education, 2015), it is paramount to explore how negative perceptions of racial minorities can be countered to improve interracial relations among students and enhance overall campus climate. Communication scholars have found that media representations of minority groups, racial or others, can affect how audiences perceive members of these groups, especially when audiences lack meaningful personal experiences with these groups, thus relying on media images to influence their perceptions (Fujioka, 1999; Shrum, Wyer, \& O'Guinn, 1998). Scholars have also determined that a critical understanding of how media messages are created (e.g., media literacy skills) can moderate the potential effects such messages have on audiences (Grossberg, Wartella, Whitney, \& Wise, 2006; Jeong, Cho, \& Hwang, 2012).

Media literacy, which focuses on audiences' ability to critically analyze and develop media messages (Aufderheide, 1993; Dennis, 2004), has been successfully used to counter the influence media can have on audiences' perceptions of and behavior concerning specific topics (Jeong, Cho, \& Hwang, 2012). The effectiveness of media literacy has prompted Scharrer and Ramasubramanian (2015) to argue that such programs may also counter the negative effects of media images on audiences' perceptions of racial minority groups. Yet, media literacy is often overlooked as a strategy to improving interracial relationships and enhancing campus climate. To address this gap, this present study reports on the development and implementation of media literacy interventions to enhance attitudes toward Blacks and Latinos among college students at a predominantly white university.

\section{Literature review}

\section{Media stereotypical representations of Blacks and Latinos}

Blacks and Latinos belong to two distinct cultures and find themselves in the United States for different historical reasons. However, when it comes to media representations, images of Blacks and Latinos have been dominated by similar stereotypes that paint an unfavorable picture of them (Dixon \& Linz, 2000; Larson, 2006; Mastro \& Behm-Morawitz, 2005). Black and Latino characters in entertainment shows are mostly pictured as poor, uneducated, and aggressive (Abraham \& Appiah, 2006; Chávez, 2008; Glascock, 2003; Ramírez-Berg, 2002). The majority of news stories about Blacks deals with crime (Entman, 1994) and crime news portrays Black and Latino criminal suspects more frequently and more menacingly than White suspects (Dixon \& Linz, 2000; Gilliam \& Iyengar, 2000; Hurwitz \& Peffley, 1997; Mastro, Lapinski, Kopacz, \& Behm-Morawitz, 2009).

Black characters in television programs "were judged as the laziest and the least respected; their dress was the most provocative and most disheveled" (Mastro \& Greenburg, 2000, p. 700). Representations of Blacks in advertisements are not any better, as advertisements featuring Black models incorporated "subtle racists 
elements that suggest inferiority," such as appearing in the background, being cast as workers (as opposed to bosses), limiting time on-screen, and not being active (Bristor, Lee, \& Hunt, 1995, p. 56). They are also portrayed in nonoccupational roles, as opposed to being portrayed in business or work-related settings (Bailey, 2006) or serve a token/subordinate role (Ball, Liang, \& Lee, 2009; Hollerbach, 2009).

Representations of Latinos in the news are dominated by images of immigrants, referred to as "illegal aliens" or "illegal immigrants," generally threatening U.S. domestic populations (Chávez, 2008; Santa Ana, 2002; Steinberg, 2004). News stories mostly use unfavorable language to describe undocumented immigrants (Mastro, Tukachinsky, Behm-Morawitz, \& Blecha, 2014) and tend to associate them with criminal activities (Catalano \& Waugh, 2013; Steinberg, 2004). In entertainment media, Latino characters are often the least intelligent and are associated with criminal activities, both in their conversations and actions (Mastro \& BehmMorawitz, 2005; Mastro \& Greenberg, 2000). Representations of Blacks and Latinos as lawbreakers and unintelligent are even found in the most popular user-generated YouTube videos, with Blacks portrayed stereotypically in $70 \%$ of the videos featuring Black characters and Latinos portrayed stereotypically in all but one video out of more than 100 (Guo \& Harlow, 2014).

Even more favorable representations can be stereotypical. For instance, representations of Blacks as successful entertainers and athletes may imply that they are performers and not intellectuals (Czopp, Kay, \& Cheryan, 2015). Indeed, several studies have revealed that favorable representations of Blacks as football or basketball players are often associated with stereotypes of innate athletic abilities and contrasted with images of White athletes possessing intellectual abilities (Billings, 2004; Eastman \& Billings, 2001; Lavelle, 2010; Mercurio \& Filak, 2010). For instance, focusing on print media descriptions of quarterbacks, football's most prominent position, Mercurio and Filak (2010) concluded that Black quarterbacks were "overwhelmingly portrayed as being very athletic but lacking mental abilities" (p. 67). Athletic "positive" or "complimentary" stereotypes can lead to negative stereotypical views about Blacks (Biernat \& Manis, 1994; Czopp \& Monteith, 2006; Stone, Perry, \& Darley, 1997), as "people who are likely to praise Blacks for their supposed athletic and music ability are also likely to denigrate Blacks for their laziness and criminality" (Czopp \& Monteith, 2006, p. 245).

\section{Media effects on perceptions of Blacks and Latinos}

Media stereotypical representations of Blacks and Latinos have the power to teach audiences about people they know little or nothing about (Faber, O'Guinn, \& Meyer, 1987; Grossberg, Wartella, Whitney, \& Wise, 2006). Ramasubramanian (2010) explained that "when televised portrayals of African-Americans and LatinoAmericans repeatedly elicit negative emotions such as fear, anger, dislike, or nervousness, such feelings become strongly entrenched in the memory structure, making them accessible when evaluating feelings toward these racial outgroups in the real world" (p. 116). Furthermore, the effects of media representations of racial 
minorities on audiences' unfavorable perceptions of members of these groups are stronger for audiences who perceive media images as credible (Melican \& Dixon, 2008).

Survey research has established a positive correlation between nonstudent adults' television viewing and stereotypical perceptions of Blacks as dangerous (Dixon, 2008), and nonstudent audiences who follow news stories about Latino immigration are more likely to support proposals opposing immigration (Valentino, Brader, \& Jardina, 2013). College students are not immune to the effects of these media messages. For instance, there is a positive correlation between college students' exposure to news and stereotypical perceptions of Blacks (Fujioka, 1999; Tan, Fujioka, \& Tan, 2000). Similarly, Ramasubramanian (2010) found a relationship between participants' perceptions of negative portrayals of Blacks and Latinos, and stereotypical beliefs about laziness and criminality toward Blacks and Latinos. Furthermore, college students who are heavy television viewers are more likely to perceive Latinos as more violent, less intelligent, and lazier - all of which are prominent media stereotypes of Latinos - than light television viewers (Mastro, Behm-Morawitz, \& Ortiz, 2007).

Exploring causal relationships between media exposure and perceptions, researchers have found that stereotypical media portrayals of Blacks led to negative perceptions of Black people from college students (Ford, 1997) and nonstudent adults (Oliver, 2003). All studies referenced below were conducted with college samples; their findings underscore the importance of exploring ways to counter the effects of media images to enhance students' racial attitudes. Unfavorable language in news stories about undocumented immigrants results in more unfavorable attitudes about Latinos (Mastro,, Tukachinsky, Behm-Morawitz, \& Blecha, 2014). Even a single exposure to negative portrayals can produce stereotype-based responses (Mastro, Lapinski, Kopacz, \& Behm-Morawitz, 2009). News content, in particular, draws explicit attention to the relation between race and crime, which can influence audiences' beliefs regarding racial groups and punitive policies (Dixon, 2006; Johnson, Adams, Hall, \& Ashburn, 1997; Oliver \& Fonash, 2002; Oliver, Jackson, Moses, \& Dangerfield, 2004).

Although there is a wealth of studies investigating media representations of Blacks and Latinos, as well as how these representations affect college students' perceptions of Black and Latino people in general, there is a dearth of research exploring how to counter such media effects and reduce these misperceptions (Ramasubramanian, 2007; Scharrer \& Ramasubramanian, 2015). Developing the skills to critically analyze media messages represents one of the strategies that could effectively mitigate the influence media have on college students' stereotypical perceptions of racial minorities.

\section{Effectiveness of media literacy interventions}

Media literacy is traditionally defined as "an individual's ability to access, analyze, evaluate and produce information for specific outcomes" (Aufderheide, 1993, p. 6). Interventions are primarily designed with a cognitive-based foundation, aiming to 
strengthen participants' critical analysis of media messages while downplaying the alluring and often unrealistic nature of media representations (Austin \& Meili, 1994; Banerjee \& Greene, 2007; Chen, 2013; Pinkleton, Austin, Chen, \& Cohen, 2012; Potter, 2004b). Hands-on activities and interactive discussions, such as deconstructing media messages and producing counter messages, are designed to encourage participants to question the motives of media producers, analyze embedded values and perspectives in messages, and investigate the missing components in media messages. The effectiveness of media literacy interventions is well-documented, particularly in the context of health behaviors, as a recent meta-analysis found that media literacy interventions have successfully enhanced participants' media knowledge, attitudes, self-efficacy, and health behaviors (Jeong, Cho, \& Hwang, 2012).

In terms of stereotypes' reduction and improvement in interracial relations, media literacy programs implemented abroad have reduced the stereotypes that Israeli and Palestinian children held of each other (Cole et al., 2003) and enhanced young adults' social acceptance of interethnic marriage and empathy toward other ethnic groups in Rwanda (Paluck, 2009). Both studies, however, took a passive approach, only showing positive media messages representing mutual respect and reconciliation to educate participants without engaging in active discussions.

The success of such programs implemented in other countries where racial/ethnic tension is high indicates media literacy programs' utility and applicability in improving U.S. college students' racial attitudes. However, the approach taken by Cole et al. (2003) and Paluck (2009), may not be as appropriate or easily implementable with college students, who are more engaged with media and tend to balance demanding school and work schedules. In addition, prior known media literacy programs have focused on analyzing and evaluating different aspects of media messages (e.g., message values, persuasion tools embedded, and realism) without reflecting on how one's own sociocultural background (e.g., race, gender, SES) can impact the ways in which messages are interpreted. Indeed, perceptions of one's and others' identity add nuances and provide insight into media literacy program design, particularly as it pertains to race. Contrary to the traditional media literacy programs, critical media literacy emphasizes the role of culture and identity in exploring interactions with media images and their potential influence.

\section{Critical media literacy and attitudes toward racial minority groups}

Critical media literacy posits that media messages reflect a society's culture and shape audiences' perceptions of social issues (Alvermann \& Hagood, 2000). These messages play a prominent role in influencing how viewers identify themselves and others. They, in particular, "can also affect our beliefs about ourselves and about others from different race, class, gender, and sexual orientation groups" (Tisdell, 2008, p. 52). In other words, critical media literacy emphasizes how media create specific identities through repetition of depictions associated with particular identities, which then become part of a society's social norm (Grossberg, Wartella, Whitney, \& Wise, 2006). 
Critical media literacy can provide depth and breadth to racial identity discussions. This approach encourages audiences to think critically not only about media (e.g., who creates the messages and why) but also about how these messages affect our perceptions of people who identify with other social groups (Tisdell \& Thompson, 2007; Yosso, 2002). This approach has been used in several media literacy programs for various topics such as reducing gender stereotypes (Walsh, Sekarasih, \& Scharrer, 2014), improving body image (Chambers \& Alexander, 2007; Wade, Davidson, \& O’Dea, 2003), and understanding media violence (Scharrer, 2006).

In one of the few published studies on media literacy and racial attitudes in the United States, Ramasubramanian (2007) exposed college students to a combination of critical media literacy intervention (intervention vs. control) and media stereotypes (stereotypes vs. counter stereotypes) and then asked students to complete a timed-word association task immediately following the intervention. She found that participants who were exposed to a 12 -min video on critical media literacy and to examples of counter-stereotypical images of Blacks reported lower levels of stereotype activation toward Blacks than other participants. Ramasubramanian concluded that more research is needed to investigate the relationship between media literacy and racial attitudes, a call Scharrer and Ramasubramanian (2015) recently renewed in their review of media literacy interventions aiming to reduce racial/ethnic stereotypes.

\section{Theoretical framework and present study}

As mentioned above, most media literacy interventions take a cognitive-based approach that stimulates critical thinking. This cognitive information processing framework enhances the saliency of how messages are constructed in audiences' mind as they consume media and allows the audience to use that knowledge to make sense of media messages (Potter, 2004a). There are two main cognitive routes for audiences to process information: heuristic and systematic processing (Chaiken, 1980). Heuristic processing uses few cognitive resources, as audiences respond/react spontaneously to media messages. On the contrary, systematic processing requires considerable cognitive effort, as audiences evaluate the validity of media messages and think about their responses/reactions to these messages (Chaiken, 1980; Shrum, 2001, 2009). Chaiken (1980) explained that heuristic processing "de-emphasizes detailed information processing," whereas systematic processing "emphasizes detailed processing of message content" (p. 752).

Audiences who process media messages heuristically are more likely to be influenced by the content of media messages than audiences who process media messages systematically and for whom direct media effects can disappear (Shrum, 2009). That is, being able to think about media representations and their potential effects can diminish the influence of these representations on audiences (Shrum, 2001). However, as Potter (2004a) maintained, audiences' "interactions with the media are almost always in a state of automaticity" (p. 269). These "automatic routines" Potter described lead audiences to process media message heuristically 
by default (Shrum, 2009) and to accept media representations as natural (Kellner \& Share, 2005). Media literacy, therefore, aims to enhance systematic processing and downplay heuristic processing in order to deconstruct and critically think about media message (Scharrer, 2002).

Given (a) the current racial tensions reported on in the news, (b) continuous media stereotypical representations of racial minorities and their effects on audiences, and (c) the success of media literacy interventions in changing attitudes, it is crucial to explore how media literacy interventions could enhance college students' attitudes toward Blacks and Latinos. To this end, two media literacy interventions grounded in a cognitive information processing framework were developed, one focused on critical media literacy (critical intervention), based on the interventions mentioned above, and one focused on media stereotypes (stereotype intervention), as exposing audiences to stereotypical representations and deconstructing them is a common approach in media literacy programs (e.g., Chung, 2007; Vargas \& dePlyssler, 1998; Yosso, 2002). Both interventions aimed to display how media effects are dependent on heuristic processing and demonstrate how systematic processing can diminish the strength of these effects.

Most media literacy studies use a pre- and post-test design, collecting data sometime before the media literacy activities and upon completion of those activities, thus overlooking potential long-term effects. Indeed, in their review of 15 years (19902006) of media literacy interventions pertaining to improving the health of youth, Bergsma and Carney (2008) found that only about a quarter of these interventions tested the longer-term effects on participants, as most studies only reported effects measured immediately after the media literacy interventions. Therefore, the potential effects of the two media literacy interventions used in this study were measured immediately following the interventions and again approximately 2 months later.

Based on the findings of previous media literacy studies, we hypothesized that students would hold more favorable attitudes toward Blacks and Latinos after having participated in a media literacy intervention, compared to students who would not have participated in an intervention (H1). As mentioned above, audiences who perceive media messages as credible are more likely to be influenced by those images. Therefore, we investigated the potential effects of the media literacy interventions on students' perceptions of media reality (RQ1). In addition, given the scarcity of interventions focused on race/ethnicity, we explored the differences in the effects of the two types of media literacy interventions (RQ2). Lastly, taking into account the methodological limitations pertaining to media literacy effects, we investigated and compared the longer-term effects of the interventions (RQ3).

\section{Methods}

\section{Study design}

To answer the above research questions and test the hypothesis, we used a quasiexperiment with a sample of college students at a predominantly White university. All participants were journalism and mass communication students enrolled in five 
different sections of an introductory secondary data collection and interpretation course that did not address matters pertaining to race. Participant randomization occurred at the class section level and all instructors agreed to offer students extra credit to take part in our study. Four course sections were randomly assigned to one of the interventions (two sections per intervention), whereas the fifth course section served as a control group. The study was conducted during the 2015 fall semester and the interventions took place at mid-semester. They were led by Joseph Erba and Yvonnes Chen and lasted $75 \mathrm{~min}$ (the duration of one class session). At the end of each intervention, students completed a brief teaching evaluation form. All students in all courses were asked to complete a questionnaire at the beginning of semester, at mid-semester (after the interventions were conducted), and at the end of the semester. The three questionnaires included the same series of questions pertaining to attitudes toward Blacks and Latinos, and perceptions of media messages. The first measurement established baseline data; the second and third explored immediate and longer-term effects of the interventions, respectively (see Table 1). Authorization to conduct this project was obtained from the university's Institutional Review Board and all students read an information statement about the study prior to completing each questionnaire.

\section{Media literacy intervention content}

\section{Critical media literacy intervention}

The purpose of this intervention was to have students critically think about (a) the role media play in constructing certain visible identities and (b) how these identities affect our self-perceptions and perceptions of others. This intervention featured a brief lecture on the omnipresence of media in our lives and how media create identities. Then, we asked students to select a visible identity (gender and race) different than the one they identify with, and write down how media portray that visible identity, how others may perceive them and how they may think about themselves. We discussed what students had written on their worksheet and talked about where these perceptions may come from. After having established the role of media images, we used a series of examples to critically examine which identities are mostly represented in the media, how they are represented, and who is not represented. For each example, we asked the students to think about how these portrayals represented a broader reflection of how society views members of these groups, thus reinforcing

Table 1. Study timeline and total number of participants who completed each measurement.

\begin{tabular}{lccc}
\hline & \multicolumn{3}{c}{ Measurements } \\
\cline { 2 - 4 } Condition & $\begin{array}{c}\text { Baseline } \\
\left(1^{\text {st }} \text { week of September }\right)\end{array}$ & $\begin{array}{c}\text { Short-term effects } \\
\left(3^{\text {rd }} \text { week of October }\right)^{1}\end{array}$ & $\begin{array}{c}\text { Longer-term effects } \\
\left(1^{\text {st }} \text { week of December }\right)\end{array}$ \\
\hline Critical intervention $(n)$ & 55 & 49 & 43 \\
Stereotype intervention $(n)$ & 58 & 61 & 50 \\
Control group $(n)$ & 19 & 19 & 16 \\
\hline
\end{tabular}

${ }^{1}$ Short-term effects were measured directly following the media literacy interventions 
the identities media continue to ascribe to these groups. We concluded the intervention with a discussion on the importance of counter-portrayals of racial minorities and their potential effect on audiences.

\section{Stereotype media literacy intervention}

The purpose of this intervention was to have students (a) identify and deconstruct the main stereotypical images associated with the main racial groups in the United States and (b) think about the effects of such stereotypes on audiences. Before introducing the intervention content, we used a brief discussion on the U.S. census to have students come up with the five main U.S. racial groups for our opening activity. We distributed index cards to the students and asked them to draw a column for each of the five racial groups they had just identified (in their terms-White/Caucasian, Hispanic, African American, Asian, and Native American). Students then had 2 minutes to write down the first thoughts that came to their minds when thinking about these groups. After 2 minutes, we asked the students to move around and exchange their index card with five other students without looking at any index card until they received their fifth one. Students then read out loud the content of that index card while we wrote that information on the white board. We discussed why each group was associated with these terms and asked students to think of media images that both supported and refuted these stereotypes. We then played three selected scenes from the movie Crash to further discuss racial stereotypes. ${ }^{2}$ After each scene, students wrote down all the stereotypes they identified and we discussed their foundation and role in the movie's narrative. We selected Crash because it has been used in interventions to enhance faculty awareness about multicultural issues in the classroom (Ross, Kumagai, Joiner, \& Lypson, 2011) and in multicultural courses to encourage students to think about race, racism, and race relations (Kinefuchi \& Orbe, 2008; Villalba \& Redmond, 2008). We concluded the intervention with examples of counter stereotypical media representations of racial minority characters and how even these characters may subtly reinforce established stereotypes about their racial group

\section{Participants}

A total of 154 students were enrolled in the five sections of the course used in this quasi-experiment. Almost all of them $(n=151 ; 98.05 \%)$ completed at least one questionnaire. Only 71 participants who completed all three questionnaires were kept for data analysis to compare their responses from the beginning, middle and end of the semester. Most of them were either sophomores (59.20\%) or juniors (32.40\%). About three-quarters of participants were women (73.20\%). The majority self-identified as Caucasian or White American (83.32\%), followed by $9.86 \%$ who identified as Latino or Hispanic and 5.63\% as Black or African American. Participants' age ranged from 19 to 23 years old $(M=20.03 ; S D=.23)$. Participants consumed about 3 hours of media per day $(M=2.89 ; S D=.46)$, which included television shows, whether watched on TV or online, time spent on social media outlets, as well as other Internet 
Table 2. Characteristics of participants included in the repeated-measures analyses of variable.

\begin{tabular}{lccc}
\hline & \multicolumn{3}{c}{ Condition } \\
\cline { 2 - 4 } Characteristics & $\begin{array}{c}\text { Critical intervention } \\
\text { (2 course sessions) }\end{array}$ & $\begin{array}{c}\text { Stereotype intervention } \\
\text { (2 course sessions) }\end{array}$ & $\begin{array}{c}\text { Control group } \\
\text { (1 course session) }\end{array}$ \\
\hline Participants $(N=71)$ & 33 & 30 & 8 \\
Men $(n=19)$ & 8 & 9 & 2 \\
Women $(n=52)$ & 25 & 21 & 6 \\
Caucasian/White $(n=62)$ & 29 & 26 & 7 \\
Age, $M(S D)$ & $19.62(.17)$ & $20.17(.17)$ & $20.29(.35)$ \\
Hours of media per day, $M(S D)$ & $3.08(.37)$ & $3.09(.38)$ & $2.51(.62)$ \\
\hline
\end{tabular}

use (see Table 2). No significant differences were found among participants' characteristics across conditions.

\section{Measures}

All items were measured on a 5-point Likert scale, ranging from 1 (strongly disagree) to 5 (strongly agree). All Cronbach's alphas can be found in Table 3.

\section{Attitudes toward Blacks and Latinos}

These attitudes represented the main dependent variables and were measured using Katz and Hass' (1988) Attitudes Toward Blacks Scale, which includes less overt items than other attitude scales and has been used in several other mass communication studies (e.g., Oliver \& Fonash, 2002; Oliver, Jackson, Moses, \& Dangerfield, 2004; Richardson, 2005). Katz and Hass' (1988) scale is composed of 10 "anti-Black" items and 10 "pro-Black items." These 20 items were also used to test participants' attitudes toward Latinos by substituting "Latinos" for "Blacks." The order in which the two scales were presented, as well as the order of the 20 items within each scale, was randomized in all three questionnaires. Sample items of the Anti-Black/Latino scale included, "On the whole, Black/Latino people don't stress education and training"

Table 3. Means and standard deviations for all dependent variables and conditions.

\begin{tabular}{lcccc}
\hline Variable & $\alpha$ & $\begin{array}{c}\text { Critical intervention } \\
M(S D)\end{array}$ & $\begin{array}{c}\text { Stereotype intervention } \\
M(S D)\end{array}$ & $\begin{array}{c}\text { Control group } \\
M(S D)\end{array}$ \\
\hline Pro-Black (baseline) & .84 & $3.23(.69)$ & $3.41(.70)^{\mathrm{c}}$ & $3.28(.76)$ \\
Pro-Black (short-term effect) & .76 & $3.47(.56)^{\mathrm{a}}$ & $3.64(.52)^{\mathrm{c}}$ & $3.38(.78)$ \\
Pro-Black (longer-term effect) & .81 & $3.24(.67)^{\mathrm{a}}$ & $3.54(.52)$ & $3.23(.83)$ \\
Anti-Black (baseline) & .88 & $2.73(.76)$ & $2.59(.84)$ & $2.06(.76)$ \\
Anti-Black (short-term effect) & .88 & $2.49(.71)$ & $2.71(.95)$ & $2.16(.84)$ \\
Anti-Black (longer-term effect) & .89 & $2.71(.86)$ & $2.67(.75)$ & $2.20(.61)$ \\
Pro-Latino (baseline) & .81 & $3.26(.50)$ & $3.34(.64)^{\mathrm{d}}$ & $3.28(.63)$ \\
Pro-Latino (short-term effect) & .70 & $3.44(.46)^{\mathrm{b}}$ & $3.59(.44)^{\mathrm{d}}$ & $3.27(.57)$ \\
Pro-Latino (longer-term effect) & .80 & $3.21(.59)^{\mathrm{b}}$ & $3.45(.54)$ & $3.27(.58)$ \\
Anti-Latino (baseline) & .84 & $2.52(.65)$ & $2.46(.69)$ & $2.34(.70)$ \\
Anti-Latino (short-term effect) & .83 & $2.37(.63)$ & $2.44(.69)$ & $2.20(.66)$ \\
Anti-Latino (longer-term effect) & .84 & $2.58(.65)$ & $2.53(.69)$ & $2.10(.50)$ \\
Media reality (baseline) & .61 & $2.63(.74)$ & $2.47(.77)$ & $2.71(.89)$ \\
Media reality (short-term effect) & .74 & $2.40(.82)$ & $2.32(.92)$ & $2.19(.88)$ \\
Media reality (longer-term effect) & .78 & $2.48(.70)$ & $2.26(.73)$ & $2.24(1.08)$ \\
\hline
\end{tabular}

Note. Means with the same superscript differ significantly at $p<.05$. 
and "Very few Black/Latino people are just looking for a free ride" (reversed coded). Sample items of the Pro-Black/Latino scale included, "Black/Latino people do not have the employment opportunities that Whites do" and "Most Blacks/Latinos are no longer discriminated against" (reverse coded).

\section{Perceptions of media reality}

Participants answered questions evaluating their perceptions of the accuracy of media messages in general. That is, how real did they perceive media representations to be? A four-item perception of television reality scale was adapted from Rosenkoetter, Rosenkoetter, Ozretich, and Acock (2004) study about harmful effects of exposure to violent television content. Sample items included, "Television presents personality characteristics as they are in real life" and "Television lets me really see the occupational roles of different people in the U.S." Participants were instructed to think back to the television shows, such as movies, series, and reality shows they watch on an actual television or on their laptop, tablet or smartphone.

\section{Intervention evaluation}

Participants who attended an intervention completed a brief evaluation form about (a) their perceptions of the intervention and (b) of the intervention instructors, as well as (c) how much the intervention made them think about the effects of media messages on self-perceptions and perceptions of people who belong to different racial groups.

\section{Results}

All data were analyzed in SPSS (version 22). Composite scores were created for all dependent variables at the three measurement times. Composite scores were also created for the three intervention teaching evaluation variables: perception of intervention $(\alpha=.81)$, perception of instructors $(\alpha=.83)$, and thinking about media $(\alpha=.86)$. A series of independent sample $t$-tests between the critical media literacy and the stereotype media literacy interventions revealed no significant differences for the three intervention evaluation variables. Similarly, no significant differences were found between the two critical media literacy interventions as well as between the two stereotype media literacy interventions for the three intervention teaching evaluation variables, thus revealing that participants in the different sections perceived the interventions and the instructors similarly.

To test the hypothesis that students would hold more favorable attitudes toward Blacks and Latinos after having participated in a media literacy intervention (H1), and to answer the research questions investigating potential interventions' effects on participants' perceptions of media reality (RQ1), comparing the two types of interventions (RQ2) and their longer-term effects (RQ3), three repeated-measures ANOVAs (one for each condition: critical intervention; stereotype intervention; control group) were conducted with participants' anti- and pro-Black/Latino attitudes and perception of media reality as dependent variables. Means and standard 
deviations for all dependent variables are reported in Table 3 (minimum and maximum values for all variables are reported in the appendix).

\section{Critical media literacy intervention}

Results revealed a main effect of the intervention on participants' pro-Black, $F(2,58)=5.55, p<.05, \eta_{p}^{2}=.16$, and pro-Latino, $F(2,58)=5.29, p<.05, \eta^{2} p$ $=.15$, attitudes. Bonferroni post hoc analyses indicated that after having attended the intervention, participants' pro-Black $(M=3.47, S D=.56)$ and pro-Latino $(M$ $=3.44, S D=.46)$ attitudes were marginally higher than at the beginning of the semester $\left(M=3.23, S D=.69\right.$, and $M=3.26, S D=.50$, respectively) ${ }^{3}$ However, by the end of the semester, participants' pro-Black $(M=3.24, S D=.67)$ and pro-Latino $(M=3.21, S D=.59)$ attitudes were significantly lower than after the intervention, thus suggesting that the small effect of the intervention had disappeared by then. No significant differences were found for any of the other dependent variables (anti-Black/Latino attitudes and perceptions of media reality).

\section{Stereotype media literacy intervention}

Results revealed a main effect of the intervention on participants' pro-Black, $F(2,56)$ $=4.23, p<.05, \eta_{p}^{2}=.13$, and pro-Latino, $F(2,56)=4.49, p<.05, \eta_{p}{ }^{2}=.14$ attitudes. Bonferroni post hoc analyses indicated that after having attended the intervention, participants' pro-Black $(M=3.65, S D=.52)$ and pro-Latino $(M=3.59, S D$ $=.44)$ attitudes were significantly higher than at the beginning of the semester $(M=$ $3.41, S D=.70$, and $M=3.34, S D=.64$, respectively). ${ }^{4}$ Furthermore, there were no significant differences with participants' pro-Black $(M=3.54, S D=.52)$ and proLatino $(M=3.45, S D=.54)$ attitudes at the end of the semester, thus suggesting that the effects of the intervention may have endured. Similar to the critical media literacy intervention, no differences were found for the other dependent variables.

\section{Control group}

No significant differences were found for any of the dependent variables. ${ }^{5}$

Our hypothesis is partially supported as intervention participants displayed higher levels of pro-Black and pro-Latino attitudes after the interventions, whereas control group participants' attitudes toward Black and Latinos did not change throughout the semester. However, the interventions did not decrease participants' levels of anti-Black and anti-Latino attitudes.

Our research questions pertained to investigating potential interventions' effects on participants' perceptions of media reality, as well as comparing the two types of interventions and their longer-term effect. Results revealed that the interventions had no effect on participants' perceptions of media reality. Comparing effects of the interventions, the stereotype media literacy intervention was more effective than the critical media literacy intervention at enhancing participants' pro-Black and 
pro-Latino attitudes. The stereotype intervention also seemed to have a longer-term effect on participants' attitudes. However, it is important to keep in mind that neither intervention had any effect on participants' anti-Black and anti-Latino attitudes.

\section{Discussion}

Media literacy seems to work to enhance students' attitudes toward Blacks and Latinos. However, the media literacy interventions did not decrease students' stereotypical beliefs about Blacks and Latinos nor did the interventions affect students' perceptions of media reality. Students who took part in one of two types of media literacy interventions reported more favorable attitudes toward Blacks and Latinos than they had just a few months earlier. In contrast, students who did not take part in a media literacy intervention did not change their attitudes toward Blacks and Latinos throughout the semester. Although the two interventions enhanced students' short-term racial attitudes, they did so with varied effects and also resulted in different longer-term outcomes. Students in the critical media literacy intervention reported marginally more favorable racial attitudes after the intervention, compared to significantly more favorable racial attitudes for students in the stereotype media literacy intervention. In addition, at the end of the semester, students who had attended the critical media literacy intervention reported significantly less favorable racial attitudes than they had a few months earlier, after the intervention, thus suggesting that the small effect of the intervention had dissipated by then. On the contrary, during the same time frame, the more favorable racial attitudes measured after the stereotype media literacy intervention remained.

From a cognitive information processing perspective, the stereotype intervention was more successful than the critical intervention in engaging students to process information systematically, as students in the critical intervention seem to revert back to heuristic processing by the end of the semester. These outcomes could be partially explained by the intervention content. The critical media literacy intervention was more conceptual than the stereotype intervention. It introduced students to media and identity theories and encouraged them to think about media from the perspective of a racial other. It was structured like a traditional class session, with a lecture, activity, discussion, and examples. The stereotype intervention, on the other hand, was more interactive. It started with an activity meant to get students out of their "comfort zone" by writing down the first thoughts that came to their minds when thinking about different racial groups. These thoughts, most of them reflective of media stereotypical portrayals, were then written on the white board for all to see and discuss. Therefore, even though both interventions dealt with stereotypes, media effects and systematic message processing, the critical intervention focused on analyzing and thinking about the effects of media images, whereas the stereotype intervention focused on identifying and deconstructing media stereotypes, which has been a standard approach in prior media literacy programs. This higher level of engagement with media messages can be associated with a higher motivation to process information systematically (Shrum, 2009). 
Findings suggest that directly addressing media stereotypes may be more effective than talking about them at a conceptual level. Students in the stereotype intervention experienced first-hand how pervasive these media stereotypes are, as they wrote them down when thinking about racial groups and saw that their peers had written similar ones. This particular activity may have forced students to confront how members of racial minority groups are perceived and the role media play in creating and recreating such representations. Many students in the stereotype intervention seemed shocked when we asked them to exchange their note cards with others. Such a reaction did not occur at any point in the critical media literacy intervention. The "shock value" of the stereotype intervention may have contributed to stronger short-term effects than the ones elicited by the critical intervention and to the endurance of these effects a few months later.

Although the interventions positively influenced students' pro-Black and -Latino attitudes, they did not affect anti-Black and -Latino attitudes. It is unclear why students would have processed information from the "anti" and "pro" scales differently. Scharrer (2002) stated that media literacy interventions that aim to increase critical thinking can elicit different responses from participants based on the types of questions/scales used. Statements used for the "anti" scale are more overt than the ones used for the "pro" scale. Most students have probably been socialized in an environment that would not publicly accept overt racist comments. Therefore, students' responses may reflect a social desirability bias. Other researchers have addressed the different types of responses elicited by subtle and overt racist items (Mastro, BehmMorawitz, \& Kopacz, 2008; Yoo, Steger, \& Lee, 2010) and have been using scales to measure "modern" or "symbolic" racism instead, which include items similar to the ones in the "pro" scale measuring racial attitudes (Melican \& Dixon, 2008; Sears \& Henry, 2003).

It is important to note, however, that even though the "anti" scale uses more overt items, students' anti-Black and -Latino attitudes did not decrease after the interventions, when students should have displayed less unfavorable attitudes toward Blacks and Latinos. Referring to outcomes of media literacy interventions, Scharrer (2002) posited that "critical thinking cannot always lead neatly to resistance to the media's effects" (p. 356). Yet, a media literacy intervention by Ramasubramanian (2007) resulted in a reduction of stereotype activation toward Blacks, measured by a timed-word association activity. Although Ramasubramanian's measures may not be completely comparable to ours, her findings indicate that media literacy can be successfully used to decrease misperceptions of Blacks.

Our interventions did not have an influence on students' perceptions of media reality, which should have decreased after the interventions. Such findings are inconsistent with the conclusion from a meta-analysis (Jeong, Cho, \& Hwang, 2012) but may be reflected by the sample we recruited. As journalism and mass communication majors, students in this study may already feel a certain way about media and reality, and therefore may be less likely to change their perceptions on the matter, especially after only one intervention. In addition, contrary to the racial attitude scales, the items used to measure perceptions of media reality did not refer to any 
specific racial group or to race in general. Therefore, students may not have made the connection between media misrepresentations of Blacks and Latinos emphasized in both interventions, and the accuracy of media content in general.

As we think about the study's findings and implications, it is important to note its limitations. We used a quasi-experimental design that only included one intervention in the treatment groups. Additional interventions may have provided a more nuanced understanding of the relationship between media literacy and racial attitudes. Nevertheless, the value of such designs has been established in previous studies, as one-shot, single lesson interventions resulted in enhancing attitudes and changing behavioral intentions (Brown, 2006). Findings are also based on a relatively small sample size, especially because our repeated-measure analysis could only include students who had completed all three questionnaires, and the majority of participants were White women. Results should therefore be confirmed with a larger, more racially and gender balanced, and overall more diverse sample, especially considering that only journalism and mass communication students took part in this study and they may think about media images differently than students from other majors. Lastly, the scales used in this study only addressed racial identity and did not give students the opportunity to respond to statements pertaining to the intersection of identities, such as gender (e.g., Black men vs. Black women) or age (e.g., young Latinos vs. middle-aged Latinos).

Researchers should take those limitations into account as they continue to investigate effects of media literacy programs on students' racial attitudes. More attention should also be given to participants' characteristics and individual differences. For instance, amount of TV consumption (Mastro, Behm-Morawitz, \& Ortiz, 2007), level of dogmatism and altruism (Rada, 2000), or interactions with members from other racial/ethnic groups (Emerson, Kimbro, \& Yancey, 2002) can influence audiences' perceptions of racial/ethnic minorities. Participants' characteristics could also be taken into account to tailor the design and content of interventions. In addition, future studies should explore different types of media literacy interventions that go beyond implementing just one intervention. Students could be asked to keep a journal of their media consumption for a certain number of days, pay attention to representations of racial/ethnic minorities and respond to specific reflection questions about the messages to which they are being exposed. In another intervention, students could create their own media messages, challenging racial/ethnic media stereotypes. Lastly, moving beyond attitudes, future research should investigate if media literacy programs can influence students to advocate for positive media portrayals of racial/ethnic groups and to enhance race relations or other related causes.

\section{Conclusion}

Although media literacy interventions have been successfully used to counter media messages pertaining to various issues (e.g., alcohol and tobacco use; violent behavior; eating disorders/body image; sex education), little is known about racial attitudes. This study contributes to this field by investigating how media literacy 
interventions based on cognitive information processing influence college students' attitudes toward Blacks and Latinos. It also compared two different approaches to media literacy and explored both short-term and longer-term effects of the media literacy interventions. Findings suggest that solely taking part in a one-shot, single media literacy intervention that actively engages students to identify and deconstruct racial stereotypes can be enough to enhance their pro-attitudes toward Blacks and Latinos.

This study provides a model for a media literacy intervention that could be used at predominantly White universities to assist in efforts to create a more welcoming environment for all students. University administrators should include aspects of media literacy in first-year student orientations and should regularly organize media literacy programs to reinforce critical analysis and systematic processing of stereotypical media representations. The activities used in this study's interventions could also be adapted to classroom activities. For instance, faculty should encourage discussions pertaining to racial matters and develop activities that challenge common misperceptions about race. Such matters are often misperceived as liberal arts and social sciences topics that have no place in a STEM (science, technology, engineering, and math) curriculum. However, discussing the origin of race in science courses could demystify the notion of race as a biological concept and the STEM field could benefit from a critical discussion of its lack of racial and gender diversity.

\section{Notes}

1. In March 2015, fraternity members at the University of Oklahoma were recorded signing a racist song. In October 2015, fraternity members at Ithaca College organized a party with anti-Blacks stereotypes. In November 2015, White students at Claremont McKenna College in California organized a Halloween party mocking Mexican culture. In November and December 2015, students at the University of Missouri, Emory University, Indiana University and Western Washington University used the anonymous social media Yik Yak to threaten racial minority students.

2. Released in 2004, Crash addresses the racial and social tensions in Los Angeles from the perspective of different characters. It offers a more nuanced representation of racism than traditional victim vs offender approaches.

3. A repeated-measure ANOVA conducted with participants who completed two of the three questionnaires, the first one at the beginning of the semester and the second one after their participation in the critical media literacy intervention $(n=39)$, confirmed those results with a slightly larger effect size: $\mathrm{F}(1,38)=8.10, p<.01, \eta^{2}{ }_{p}=.18$, for participants' proBlack attitudes and $\mathrm{F}(1,38)=10.62, p<.01, \eta^{2} p=.22$ for their pro-Latino attitudes.

4. Similar to the results for the previous intervention, a repeated-measure ANOVA conducted with participants in the stereotype media literacy intervention who only completed the first two questionnaires $(n=46)$ also confirmed those results with a slightly larger effect size: $\mathrm{F}(1$, $45)=16.59, p<.001, \eta_{p}^{2}=.27$ for participants' pro-Black attitudes and $\mathrm{F}(1,45)=11.75$, $p<.01, \eta^{2}{ }_{p}=.21$ for their pro-Latino attitudes.

5. Such results were also confirmed by analyzing data from participants in the control group who only completed the first two questionnaires $(n=13)$. 


\section{References}

Abraham, L., \& Appiah, O. (2006). Framing news stories: The role of visual imagery in priming racial stereotypes. Howard Journal of Communications, 17(3), 183-203. doi:10.1080/10646170600829584.

Alvermann, D. E., \& Hagood, M. C. (2000). Critical media literacy: Research, theory, and practice in "New Times." The Journal of Educational Research, 93(3), 193-205. doi:10.1080/00220670009598707.

Aufderheide, P. (1993). Media literacy. A report of the national leadership conference on media literacy. Washington, DC: Aspen Institute, Communications and Society Program.

Austin, E. W., \& Meili, H. K. (1994). Effects of interpretations of televised alcohol portrayals on children's alcohol beliefs. Journal of Broadcasting \& Electronic Media, 38(4), 417-435. doi:10.1080/08838159409364276.

Bailey, A. A. (2006). A year in the life of the African-American male in advertising: A content analysis. Journal of Advertising, 35(1), 83-104. doi:10.2753/JOA0091-3367350106.

Ball, J. G., Liang, A., \& Lee, W. N. (2009). Representation of African Americans in direct-to-consumer pharmaceutical commercials: A content analysis with implications for health disparities. Health Marketing Quarterly, 26(4), 372-390. doi:10.1080/07359680903304328.

Banerjee, S. C., \& Greene, K. (2007). Antismoking initiatives: Effects of analysis versus production media literacy interventions on smoking-related attitude, norm, and behavioral intention. Health Communication, 22(1), 37-48. doi:10.1080/10410230701310281.

Bergsma, L. J., \& Carney, M. E. (2008). Effectiveness of health-promoting media literacy education: A systematic review. Health Education Research, 23(3), 522-542. doi:10.1093/her/cym084.

Biernat, M., \& Manis, M. (1994). Shifting standards and stereotype-based judgments. Journal of Personality and Social Psychology, 66(1), 5-20. doi:10.1037/0022-3514.66.1.5.

Billings, A. C. (2004). Depicting the quarterback in black and white: A content analysis of college and professional football broadcast commentary. Howard Journal of Communications, 15(4), 201-210. doi:10.1080/10646170490521158.

Bristor, J. M., Lee, R. G., \& Hunt, M. R. (1995). Race and ideology: African-American images in television advertising. Journal of Public Policy \& Marketing, 14(1), 48-59.

Brown, J. (2006). Media literacy has potential to improve adolescents' health. Journal of Adolescent Health, 39(4), 459-460. doi:10.1016/j.jadohealth.2006.07.014.

Carter, R. T. (1990). The relationship between racism and racial identity among White Americans: An exploratory investigation. Journal of Counseling \& Development, 69, 46-50. doi:10.1002/j.1556-6676.1990.tb01455.x.

Catalano, T., \& Waugh, L. R. (2013). The ideologies behind newspaper crime reports of Latinos and Wall Street/CEOs: A critical analysis of metonymy in text and image. Critical Discourse Analysis, 10(4), 406-426. doi:10.1080/17405904.2013.813774.

Chaiken, S. (1980). Heuristic versus systematic information processing and the use of source versus message cues in persuasion. Journal of Personality and Social Psychology, 39(5), 752766. doi:10.1037/0022-3514.39.5.752.

Chambers, K. L., \& Alexander, S. M. (2007). Media literacy as an educational method for addressing college women's body image issues. Education, 127(4), 490-497.

Chávez, L. R. (2008). The Latino threat: Constructing immigrants, citizens, and the nation. Stanford, CA: Stanford University Press.

Chen, Y. (2013). The effectiveness of different approaches to media literacy in modifying adolescents' responses to alcohol. Journal of Health Communication, 18(6), 723-739. doi:10.1080/10810730.2012.757387. 
Chung, S. K. (2007). Media literacy art education: Deconstructing lesbian and gay stereotypes in the media. International Journal of Art \& Design Education, 26(1), 98-107. doi:10.1111/j.1476-8070.2007.00514.x.

Cole, C., Arafat, C., Tidhar, C., Tafesh, W. Z., Fox, N., Killen, M., ... Yung, F. (2003). The educational impact of Rechov Sumsum/Shara'a Simsim: A Sesame Street television series to promote respect and understanding among children living in Israel, the West Bank, and Gaza. International Journal of Behavioral Development, 27(5), 409-422. doi:10.1080/01650250344000019.

Czopp, A. M., \& Monteith, M. J. (2006). Thinking well of African Americans: Measuring complimentary stereotypes and negative prejudice. Basic and Applied Social Psychology, 28(3), 233-250. doi:10.1207/s15324834basp2803_3.

Czopp, A. M., Kay, A. C., \& Cheryan, S. (2015). Positive stereotypes are pervasive and powerful. Perspectives on Psychological Science, 10(4), 451-463. doi:10.1177/1745691615588091.

Dennis, E. E. (2004). Out of sight and out of mind. The media literacy needs of grown-ups. American Behavioral Scientist, 48(2), 202-211. doi:10.1177/0002764204267264.

Deutsch, L. (2015, November 9). Mizzou president resigns: How did we get there? USA Today. Retrieved from http://www.usatoday.com/story/news/nation-now/2015/11/09/timelineuniversity-of-missouri-racism-protests-resignation/75467354/

Dixon, T. L. (2006). Psychological reactions to crime news portrayals of black criminals: Understanding the moderating roles of prior news viewing and stereotype endorsement. Communication Monographs, 73(2), 162-187. doi:10.1080/03637750600690643.

Dixon, T. L. (2008). Crime news and racialized beliefs: Understanding the relationship between local news viewing and perceptions of African Americans and crime. Journal of Communication, 58(1), 106-125. doi:10.1111/j.1460-2466.2007.00376.x.

Dixon, T. J., \& Linz, D. (2000). Overrepresentation and underrepresentation of African Americans and Latinos as lawbreakers on television news. Journal of Communication, 50(2), 131-154. doi:10.1111/j.1460-2466.2000.tb02845.x.

Eastman, T., \& Billings, A. C. (2001). Biased voices of sports: Racial and gender stereotyping in college basketball announcing. Howard Journal of Communication, 12(4), 183-201. doi:10.1080/106461701753287714.

Emerson, M. O., Kimbro, R. T., \& Yancey, G. (2002). Contact theory extended: The effects of prior racial contact on current social ties. Social Science Quarterly, 83(3), 745-761. doi:10.1111/1540-6237.00112.

Entman, R. M. (1994). Representation and reality in the portrayal of Blacks on network television news. Journalism Quarterly, 71(3), 509-520. doi:10.1177/107769909407100303.

Faber, R. J., O'Guinn, T. C., \& Meyer, T. P. (1987). Televised portrayals of Hispanics: A comparison of ethnic perceptions. International Journal of Intercultural Relations, 11, 155-169. doi:10.1016/0147-1767(87)90016-2.

Ford, T. E. (1997). Effects of stereotypical television portrayals of African-Americans on person perception. Social Psychology Quarterly, 60(3), 266-275. doi:10.2307/2787086.

Fujioka, Y. (1999). Television portrayals and African-American stereotypes: Examination of television effects when direct contact is lacking. Journalism and Mass Communication Quarterly, 76(1), 52-75. doi:10.1177/107769909907600105.

Gilliam, F. D. Jr., \& Iyengar, S. (2000). Prime suspects: The influence of local television news on the viewing public. American Journal of Political Science, 44(3), 560-573. doi:10.2307/2669264.

Glascock, J. (2003). Gender, race, and aggression in newer TV networks' primetime programming. Communication Quarterly, 51(1), 90-100. doi:10.1080/01463370309370142.

Grossberg, L., Wartella, E., Whitney, D. C., \& Wise, J. M. (2006). Producing Identities. In MediaMaking: Mass media in a popular culture (pp. 219-252). Thousand Oaks, CA: Sage. 
Guo, L., \& Harlow, S. (2014). User-generated racism: An analysis of stereotypes of African Americans, Latinos, and Asians in YouTube videos. Howard Journal of Communications, 25, 281302. doi:10.1080/10646175.2014.925413.

Hollerbach, K. L. (2009). The impact of market segmentation on African American frequency, centrality, and status in television advertising. Journal of Broadcasting \& Electronic Media, 53(4), 599-614. doi:10.1080/08838150903324014.

Hurwitz, J., \& Peffley, M. (1997). Public perceptions of race and crime: The role of racial stereotypes. American Journal of Political Science, 41(2), 375-401. doi:10.2307/2111769.

Jeong, S. H., Cho, H., \& Hwang, Y. (2012). Media literacy interventions: A meta-analytic review. Journal of Communication, 62(3), 454-472. doi:10.1111/j.1460-2466.2012.01643.x.

Johnson, J. D., Adams, M. S., Hall, W., \& Ashburn, L. (1997). Race, media, and violence: Differential racial effects of exposure to violent news stories. Basic and Applied Social Psychology, 19(1), 81-90. doi:10.1207/s15324834basp1901_6.

Katz, I., \& Hass, R. G. (1988). Racial ambivalence and American value conflict: Correlational and priming studies of dual cognitive structures. Journal of Personality and Social Psychology, 55(6), 893-905. doi:10.1037/0022-3514.55.6.893.

Kellner, D., \& Share, J. (2005). Toward critical media literacy: Core concepts, debates, organizations, and policy. Discourse: Studies in the Cultural Politics of Education, 26(3), 369-386.

Kinefuchi, E., \& Orbe, M. P. (2008). Situating oneself in a racialized world: Understanding student reactions to Crash through standpoint theory and context-positionality frames. Journal of International and Intercultural Communication, 1(1), 70-90. doi:10.1080/17513050701742909.

Larson, S. G. (2006). Hispanics in film and television entertainment. In Media \& minorities: The politics of race in news and entertainment (pp. 57-66). Lanham, MD: Rowman \& Littlefield Publishers Inc.

Lavelle, K. L. (2010). A critical discourse analysis of black masculinity in NBA game commentary. Howard Journal of Communications, 21(3), 294-314. doi:10.1080/10646175.2010.496675.

Mastro, D. E., \& Behm-Morazwitz, E. (2005). Latino representation on primetime television. Journalism \& Mass Communication Quarterly, 82(1), 110-130. doi:10.1177/107769900508200108.

Mastro, D. E., \& Greenberg, B. S. (2000). The portrayal of racial minorities on prime time television. Journal of Broadcasting and Electronic Media, 44(4), 690-703. doi:10.1207/s15506878jobem4404_10.

Mastro, D., Behm-Morawitz, E., \& Kopacz, M. A. (2008). Exposure to television portrayals of Latinos: The implications of aversive racism and social identity theory. Human Communication Research, 34, 1-27. doi:10.1111/j.1468-2958.2007.00311.x.

Mastro, D., Behm-Morawitz, E., \& Ortiz, M. (2007). The cultivation of social perceptions of Latinos: A mental models approach. Media Psychology, 9(2), 347-365. doi:10.1080/15213260701286106.

Mastro, D., Lapinski, M. K., Kopacz, M. A., \& Behm-Morawitz, E. (2009). The influence of exposure to depictions of race and crime in TV news on viewer's social judgments. Journal of Broadcasting \& Electronic Media, 53(4), 615-635. doi:10.1080/08838150903310534.

Mastro, D., Tukachinsky, R., Behm-Morawitz, E., \& Blecha, E. (2014). News coverage of immigration: The influence of exposure to linguistic bias in the news on consumer's racial/ethnic cognitions. Communication Quarterly, 62(2), 135-154. doi:10.1080/01463373.2014.890115.

Melican, D. B., \& Dixon, T. L. (2008). News on the Net: Credibility, selective exposure, and racial prejudice. Communication Research, 35(2), 151-168. doi:10.1177/0093650207313157.

Mercurio, E., \& Filak, V. F. (2010). Roughing the passer: The framing of Black and White quarterbacks prior to the NFL draft. Howard Journal of Communications, 21(1), 56-71. doi:10.1080/10646170903501328. 
Oliver, M. B. (2003). African American men as "criminal and dangerous": Implications of media portrayals of crime on the "criminalization" of African American men. Journal of African American Studies, 7(2), 3-18. doi:10.1007/s12111-003-1006-5.

Oliver, M. B., \& Fonash, D. (2002). Race and crime in the news: Whites' identification and misidentification of violent and nonviolent criminal suspects. Media Psychology, 4(2), 137156. doi:10.1207/S1532785XMEP0402_02.

Oliver, M. B., Jackson, R. L., Moses, N. N., \& Dangerfield, C. L. (2004). The face of crime: Viewers' memory of race-related facial features on individuals pictured in the news. Journal of Communication, 54(1), 88-104. doi:10.1111/j.1460-2466.2004.tb02615.x.

Paluck, E. L. (2009). Reducing intergroup prejudice and conflict using the media: A field experiment in Rwanda. Journal of Personality and Social Psychology, 96(3), 574. doi:10.1037/a0011989.

Pinkleton, B. E., Austin, E. W., Chen, Y., \& Cohen, M. (2012). The role of media literacy in shaping adolescents' understanding of and responses to sexual portrayals in mass media. Journal of Health Communication, 17(4), 460-476. doi:10.1080/10810730.2011.635770.

Pope-Davis, D. B., \& Ottavi, T. M. (1994). The relationship between racism and racial identity among White Americans: A replication and extension. Journal of Counseling \& Development, 72, 293-297. doi:10.1002/j.1556-6676.1994.tb00937.x.

Potter, W. J. (2004a). Argument for the need for a cognitive theory of media literacy. American Behavioral Scientist, 48(2), 266-272. doi:10.1177/0002764204267274.

Potter, W. J. (2004b). Theory of media literacy: A cognitive approach. Thousand Oaks, California: Sage Publications.

Rada, J. A. (2000). A new piece to the puzzle: Examining effects of television portrayals of African Americans. Journal of Broadcasting \& Electronic Media, 44(4), 704-715. doi:10.1207/s15506878jobem4404_11.

Ramasubramanian, S. (2007). Media-based strategies to reduce racial stereotypes activated by news stories. Journalism and Mass Communication Quarterly, 84(2), 249-264. doi:10.1177/107769900708400204.

Ramasubramanian, S. (2010). Television viewing, racial attitudes, and policy preferences: Exploring the role of social identity and intergroup emotions in influencing support for affirmative action. Communication Monographs, 77(1), 102-120. doi:10.1080/03637750903514300.

Ramírez-Berg, C. (2002). Latino images in film: Stereotypes, subversions and resistance. Austin, TX: University of Texas Press.

Richardson, J. D. (2005). Switching social identities: The influence of editorial framing on reader attitudes toward affirmative action and African Americans. Communication Research, 32(4), 503-528. doi:10.1177/0093650205277321.

Rosenkoetter, L. I., Rosenkoetter, S. E., Ozretich, R. A., \& Acock, A. C. (2004). Mitigating the harmful effects of violent television. Applied Developmental Psychology, 25, 25-47. doi:10.1016/j.appdev.2003.11.005.

Ross, P. T., Kumagai, A. K., Joiner, T. A., \& Lypson, M. L. (2011). Using film in multicultural and social justice faculty development: Scenes from Crash. Journal of Continuing Education in the Health Professions, 31(3), 188-195. doi:10.1002/chp.20126.

Santa Ana, O. (2002). Brown tide rising: Metaphors of Latinos in contemporary American public discourse. Austin, TX: University of Texas Press.

Scharrer, E. (2002). Making a case for media literacy in the curriculum: Outcomes and assessment. Journal of Adolescent \& Adult Literacy, 46(4), 354-358.

Scharrer, E. (2006). "I noticed more violence:" The effects of a media literacy program on critical attitudes toward media violence. Journal of Mass Media Ethics, 21(1), 69-86. doi:10.1207/s15327728jmme2101_5. 
Scharrer, E., \& Ramasubramanian, S. (2015). Intervening in the media's influence on stereotypes of race and ethnicity: The role of media literacy education. Journal of Social Issues, 71(1), 171-185. doi:10.1111/josi.12103.

Sears, D. O., \& Henry, P. J. (2003). The origins of symbolic racism. Journal of Personality and Social Psychology, 85(2), 259-275. doi:10.1037/0022-3514.85.2.259.

Shrum, L. G., Wyer, R. S., \& O’Guinn, T. C. (1998). The effects of television consumption on social perceptions: The use of priming procedures to investigate psychological processes. Journal of Consumer Research, 24, 447-458. doi:10.1086/209520.

Shrum, L. G. (2001). Processing strategy moderates the cultivation effect. Human Communication Research, 27(1), 94-120. doi:10.1093/hcr/27.1.94.

Shrum, L. G. (2009). Media consumption and perceptions of social reality: Effects and underlying processes. In J. Bryant \& M. B. Oliver (Eds.), Media effects advances in theory and research (pp. 50-73). New York, NY: Routledge.

Steinberg, S. L. (2004). Undocumented immigrants or illegal aliens? Southwestern media portrayals of Latino immigrants. Humboldt Journal of Social Relations, 28(1), 109-133.

Stone, J., Perry, W., \& Darley, J. M. (1997). "White Men Can't Jump": Evidence for the perceptual confirmation of racial stereotypes following a basketball game. Basic and Applied Social Psychology, 19(3), 291-306.

Tan, A., Fujioka, Y., \& Tan, G. (2000). Television use, stereotypes of African Americans and opinions on affirmative action: An affective model of policy reasoning. Communication Monographs, 67(4), 362-371. doi:10.1080/03637750009376517.

Tisdell, E. J. (2008). Critical media literacy and transformative learning drawing on pop culture and entertainment media in teaching for diversity in adult higher education. Journal of Transformative Education, 6(1), 48-67. doi:10.1177/1541344608318970.

Tisdell, E. J., \& Thompson, P. M. (2007). 'Seeing from a different angle': The role of pop culture in teaching for diversity and critical media literacy in adult education. International Journal of Lifelong Education, 26(6), 651-673. doi:10.1080/02601370701711349.

U.S. Department of Education. (2015). Total fall enrollment in degree-granting postsecondary institutions, by level of enrollment, sex, attendance status, and race/ethnicity of student: Selected years, 1976 through 2014. Retrieved from http://nces.ed.gov/programs/ digest/d15/tables/dt15_306.10.asp

Valentino, N. A., Brader, T., \& Jardina, A. E. (2013). Immigration opposition among U.S. Whites: General ethnocentrism or media priming of attitudes about Latinos? Political Psychology, 34(2), 149-166. doi:10.1111/j.1467-9221.2012.00928.x.

Vargas, L., \& dePlyssler, B. (1998). Using media literacy to explore stereotypes of Mexican immigrants. Social Education, 62(7), 407-412.

Villalba, J. A., \& Redmond, E. R. (2008). Crash: Using a popular film as an experiential learning activity in a multicultural counseling course. Counselor Education \& Supervision, 47, 264276. doi:10.1002/j.1556-6978.2008.tb00056.x.

Wade, T. D., Davidson, S., \& O’Dea, J. A. (2003). A preliminary controlled evaluation of a school-based media literacy program and self-esteem program for reducing eating disorder risk factors. International Journal of Eating Disorders, 33(4), 371-383. doi:10.1002/eat.10136.

Walsh, K. R., Sekarasih, L., \& Scharrer, E. (2014). Mean girls and tough boys: Children's meaning making and media literacy lessons on gender and bullying in the United States. Journal of Children and Media, 8(3), 223-239. doi:10.1080/17482798.2013.851094.

Yoo, H. C., Steger, M. F., \& Lee, R. M. (2010). Validation of the subtle and blatant racism scale for Asian American college students $\left(\mathrm{SABR}-\mathrm{A}^{2}\right)$. Cultural Diversity and Ethnic Minority Psychology, 16(3), 323-334. doi:10.1037/a0018674.

Yosso, T. J. (2002). Critical race media literacy: Challenging deficit discourse about Chicana/os. Journal of Popular Film and Television, 30(1), 52-62. doi:10.1080/01956050209605559. 


\section{Appendix}

Minimum and maximum values for all dependent variables and conditions (1-5 scale)

\begin{tabular}{|c|c|c|c|c|c|c|}
\hline \multirow[b]{2}{*}{ Variable } & \multicolumn{2}{|c|}{ Critical intervention } & \multicolumn{2}{|c|}{$\begin{array}{l}\text { Stereotype } \\
\text { intervention }\end{array}$} & \multicolumn{2}{|c|}{ Control group } \\
\hline & Min. & Max. & Min. & Max. & Min. & Max. \\
\hline Pro-Black (baseline) & 1.20 & 4.40 & 2.30 & 4.60 & 2.50 & 4.70 \\
\hline Pro-Black (short-term effect) & 1.90 & 4.60 & 2.50 & 4.50 & 2.40 & 4.90 \\
\hline Pro-Black (longer-term effect) & 1.30 & 4.40 & 2.50 & 4.50 & 2.20 & 4.20 \\
\hline Anti-Black (baseline) & 1.40 & 4.60 & 1.30 & 4.30 & 1.00 & 3.10 \\
\hline Anti-Black (short-term effect) & 1.00 & 4.10 & 1.40 & 4.80 & 1.00 & 3.10 \\
\hline Anti-Black (longer-term effect) & 1.20 & 4.80 & 1.40 & 4.40 & 1.40 & 3.10 \\
\hline Pro-Latino (baseline) & 2.00 & 4.20 & 2.00 & 4.40 & 2.20 & 4.10 \\
\hline Pro-Latino (short-term effect) & 2.40 & 4.40 & 2.50 & 4.30 & 2.60 & 4.20 \\
\hline Pro-Latino (longer-term effect) & 1.40 & 4.20 & 2.40 & 4.40 & 2.30 & 4.00 \\
\hline Anti-Latino (baseline) & 1.40 & 3.80 & 1.40 & 3.60 & 1.30 & 3.20 \\
\hline Anti-Latino (short-term effect) & 1.00 & 3.90 & 1.20 & 4.20 & 1.10 & 2.90 \\
\hline Anti-Latino (longer-term effect) & 1.40 & 3.80 & 1.20 & 4.00 & 1.20 & 2.60 \\
\hline Media reality (baseline) & 1.33 & 4.00 & 1.00 & 3.67 & 1.00 & 4.00 \\
\hline Media reality (short-term effect) & 1.00 & 4.33 & 1.00 & 4.00 & 1.00 & 3.33 \\
\hline Media reality (longer-term effect) & 1.00 & 4.00 & 1.00 & 3.67 & 1.00 & 3.67 \\
\hline
\end{tabular}

